\title{
The contribution of animal breeding to reducing the environmental impact of livestock production
}

Yvette de Haas, Wageningen University and Research, The Netherlands; Marco C. A. M. Bink, Hendrix Genetics Research, Technology \& Services B.V., The Netherlands; Randy Borg, Cobb Europe B.V., The Netherlands; Erwin P.C. Koenen, CRV, The Netherlands; Lisanne M. G. Verschuren, Topigs Norsvin Research Center B.V.Mageningen University and Research, The Netherlands; and Herman Mollenhorst, Wageningen University and Research, The Netherlands

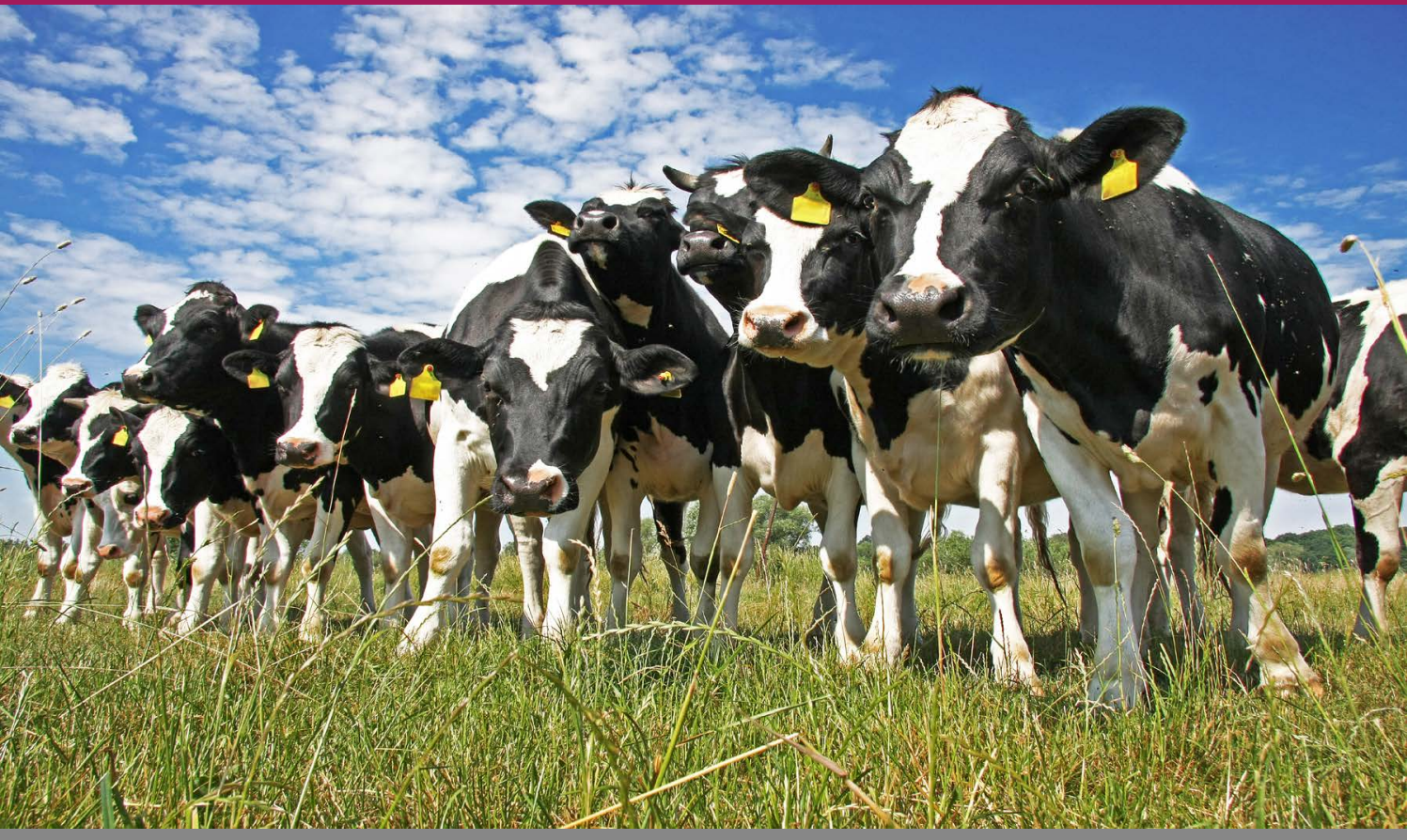

\section{b burleigh dodds}




\section{The contribution of animal breeding to reducing the environmental impact of livestock production}

Yvette de Haas, Wageningen University and Research, The Netherlands; Marco C. A. M. Bink, Hendrix Genetics Research, Technology \& Services B.V., The Netherlands; Randy Borg, Cobb Europe B.V., The Netherlands; Erwin P.C. Koenen, CRV, The Netherlands; Lisanne M. G. Verschuren, Topigs Norsvin Research Center B.V./Wageningen University and Research, The Netherlands; and Herman Mollenhorst, Wageningen University and Research, The Netherlands

1 Introduction

2 The environmental impact of livestock production

3 Broilers: environmental impact and the contribution of breeding

4 Layers: environmental impact and the contribution of breeding

5 Pigs: environmental impact and the contribution of breeding

6 Dairy cattle: environmental impact and the contribution of breeding

7 Conclusion

8 Where to look for further information

9 Acknowledgments

10 References

\section{Introduction}

The world human population is expanding, and the demand for food in the year 2050 is expected to be approximately 70\% greater than in 2010 (FAO, 2009). Demand for meat and other livestock products is highly elastic to income (Delgado et al., 1999), and therefore as population affluence improves, the demand for livestock products will increase further. Also, the global human population is ageing, and older people typically consume larger quantities of animal-derived protein than children (Steinfeld et al., 2006). The expected 70\% increase in food demand requires an annual increase in food production of 
$1.3 \%$ per annum. This increase in food demand requires an increased efficiency of food production, both animal and crop derived. Moreover, competition for land from other industries (e.g., biofuels) implies this increased animal and crop production must be achieved from an ever-declining land base. Although feed efficiency, as currently defined, is not synonymous with production efficiency, it undoubtedly will be a major contributor to increasing production from an ever-decreasing food-producing land base. The global production of red meat is expected to increase from 229 million tonnes in 1999-2001 to 465 million tonnes in 2050, while global milk production is expected to increase from 580 to 1043 million tonnes in the same period (Steinfeld et al., 2006). This increased production must, however, be achieved in an environmentally responsible and sustainable manner.

There is considerable commentary nowadays on climate change and its implications, as well as possible mitigation strategies. Animal production generates greenhouse gas (GHG) emissions as methane $\left(\mathrm{CH}_{4}\right)$ from enteric fermentation and manure, nitrous oxide $\left(\mathrm{N}_{2} \mathrm{O}\right)$ from the widespread use of nitrogenous fertilizers and animal manure and carbon dioxide $\left(\mathrm{CO}_{2}\right)$ from the fossil fuels for energy usage plus land-use change. Methane, however, is not only an environmental hazard but is also associated with a loss of carbon from the rumen and therefore an unproductive use of energy (Johnson and Johnson, 1995). There is a wide variation in documented calculations of animal agriculture contributions to GHG (Herrero et al., 2011). O'Mara (2011) stated that animal agriculture is responsible for $8.0 \%$ to $10.8 \%$ of global GHG emissions based on calculations from the Intergovernmental Panel on Climate Change (IPCC), but if complete lifecycle analysis (i.e., accounting for the production of inputs to animal agriculture as well as the change in land use such as deforestation) is undertaken, this figure can be up to $18 \%$. Cattle are the largest contributors to the global emission of $\mathrm{CH}_{4}$ from enteric fermentation (O'Mara, 2011).

In December 2015, 195 nations signed the Paris Agreement. The Paris Agreement's central aim is to strengthen the global response to the threat of climate change. Therefore, in this century, the global temperature rise should at least be kept well below $2^{\circ} \mathrm{C}$ above pre-industrial levels. To pursue efforts to limit the temperature increase even further, a more stringent aim is set to a threshold of $1.5^{\circ} \mathrm{C}$, instead of $2^{\circ} \mathrm{C}$. Additionally, the agreement aims to increase the ability of countries to deal with the impacts of climate change and to make finance flows consistent with low GHG emission and climateresilient pathways. All sectors have to reduce their environmental impact, including the livestock sector. In this chapter, we will review the current environmental impact of livestock species, show historical trends and quantify the contribution of animal breeding in reducing the environmental impact of livestock species. 


\section{The environmental impact of livestock production}

Animal production is responsible for $14.5 \%$ of total anthropogenic GHG emissions (Gerber et al., 2013). Approximately half of these emissions originate directly from animal production, whereas the other half comes from feed production. Of the total of 7.1 gigatonnes $\mathrm{CO}_{2}$-equivalents produced by the global livestock sector, beef production is responsible for $41 \%$, cattle milk production for $20 \%$, pig meat production for $10 \%$, chicken meat production for $6 \%$ and chicken egg production for $3 \%$. The remaining $21 \%$ is produced by other species and purposes, like buffalo and small ruminants for milk and meat, and by draft power, manure as fuel, and so on (Gerber et al., 2013).

Several tools have been developed to assess the environmental impacts of animal agriculture on a product basis. One of these tools is FeedPrint (Vellinga et al., 2013; Wageningen Livestock Research, 2015). FeedPrint is a life cycle analyses (LCA) tool for the assessment of environmental impacts of animal production, especially GHG emissions, developed primarily for the Dutch animal feed industry. FeedPrint, therefore, contains a full database of animal feed ingredients and their respective impacts from cradle to farmgate, including, for example, fertilizer production and application, field emissions, energy use for field work, transport and feed production. Based on data available in this tool, we could show that the GHG emissions for the production of $1 \mathrm{~kg}$ of pig meat are higher than for $1 \mathrm{~kg}$ of broiler meat, followed by chicken eggs and dairy production (Fig. 1a). Although results differ between studies, this ranking is in line with, for example, De Vries and De Boer (2010) or Williams et al. (2006). The relatively low numbers of GHG emissions for the production of milk and eggs are mainly due to the high water content of these products compared to meat and the fact that animals do not need to be slaughtered to acquire the product. When values of GHG emissions are recalculated to per kg protein basis, numbers come much closer together, with broiler meat being among the best-performing products (De Vries and De Boer, 2010; Williams et al., 2006). Beef production is outside the scope of this chapter, but, in general, calculated GHG emissions per kg product and kg protein are much higher for beef than for the other animal products.

There are different sources of GHG emissions related to animal production. The best-known and most-investigated one is enteric methane $\left(\mathrm{CH}_{4}\right)$ emission from ruminants. For dairy production, animal-related $\mathrm{CH}_{4}$ emissions account for over one-third of total GHG emissions (Fig. 1b). However, in general, about half of the GHG emissions related to animal production come from feed-production-related processes (Gerber et al., 2013). For poultry in The Netherlands, even more than $80 \%$ of GHG emissions are related to feed production (Fig. 1b), with $\mathrm{CO}_{2}$ being the predominant contributor, followed by nitrous oxide $\left(\mathrm{N}_{2} \mathrm{O}\right)$. 
(a) 3500

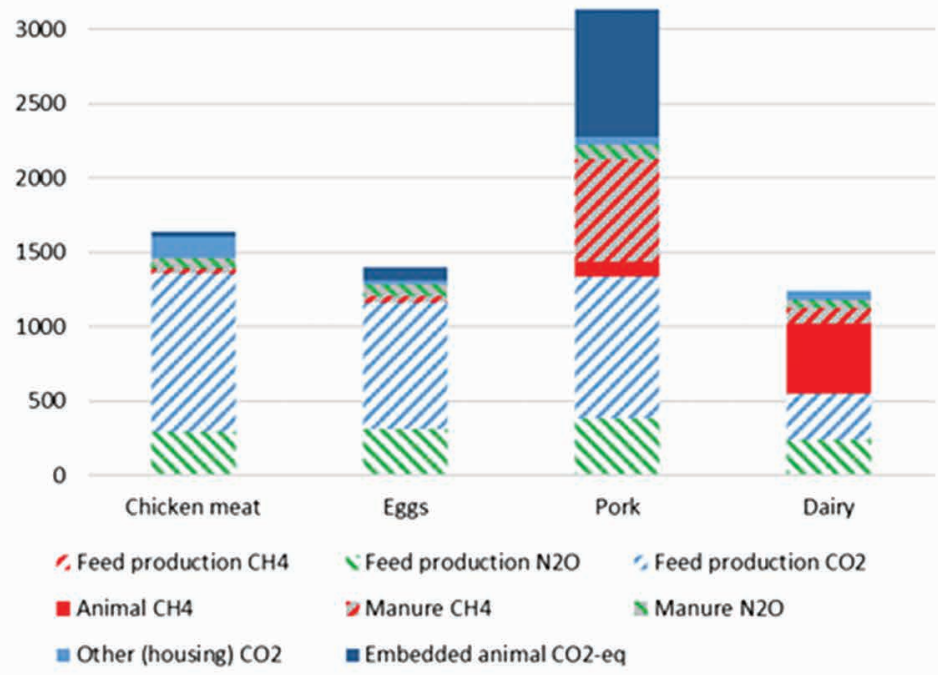

(b) $100 \%$

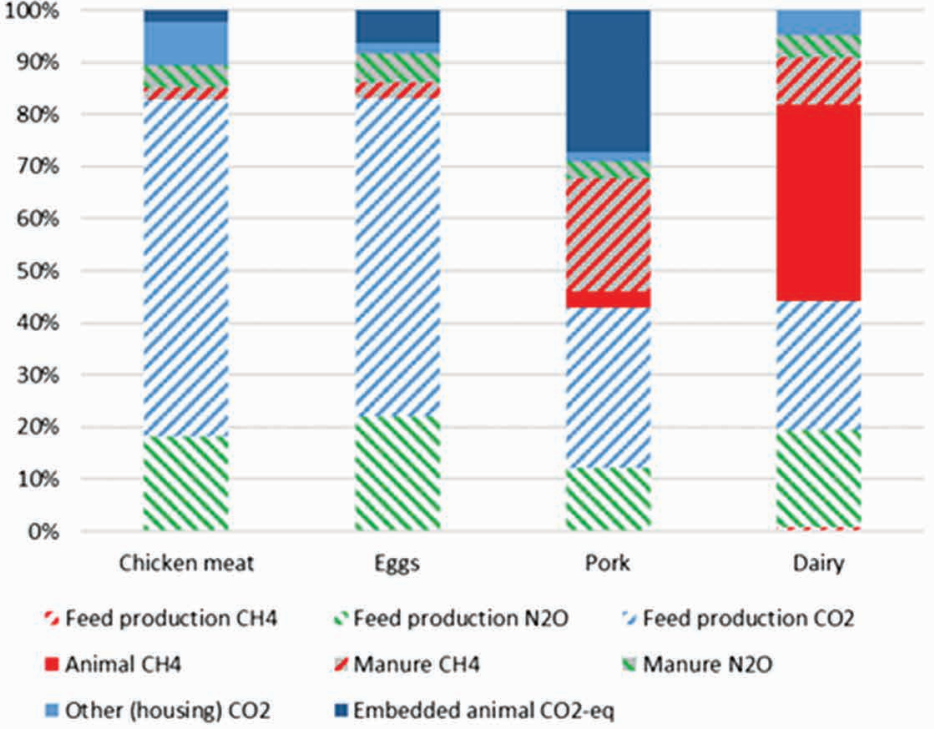

Figure 1 Greenhouse gas emissions ( $\mathrm{kg} \mathrm{CO}_{2}$-equivalents) per tonne product (a) and relative contribution (\%) to total greenhouse gas emissions (b) for four main animal products in The Netherlands based on FeedPrint (Vellinga et al., 2013; Wageningen Livestock Research, 2015). (Embedded animal = emissions caused by parent and young stock which are accounted to the final product.) 
Next to the emission of GHG, nitrogen (N)- and phosphorus (P)-related environmental impacts, like acidification, eutrophication and depletion of $\mathrm{P}$ resources, are important when animal products are concerned (e.g., Thomassen and de Boer, 2005). These impacts could be assessed using lifecycle analysis but more straightforward by nutrient balances and derived efficiency parameters (Mu et al., 2016). The efficiency of $N$ and $P$ usage at animal level seems to be a relevant indicator for animal breeding, as animal breeding aims at improving animal production and efficiently using resources, resulting in a reduction of the environmental impact. The objective of this study was to quantify the contribution of animal breeding to reducing the environmental impact of the four major livestock species in The Netherlands, namely broilers (meat), laying hens (eggs), pigs (meat) and dairy cattle (milk).

In this chapter, we will show both the historical trends and the quantification of the contribution of animal breeding to the environmental impact of several livestock species: broilers, layers, pigs and dairy cattle. At the end of the chapter is a summarizing conclusion with recommendations.

\section{Broilers: environmental impact and the contribution of breeding}

\subsection{Historical trends}

Havenstein et al. (2003) performed a study where they compared the feed conversion of broilers genetically representative of animals for the years 1957 versus 2001 when fed broiler diets representative for diets fed in 1957 and 2001. Average body weights on 42 and 84 days of age for the 1957 broiler on the 1957 diets were 539 and $1430 \mathrm{~g}$ versus 2672 and $5520 \mathrm{~g}$ for the 2001 broiler on the 2001 diets, respectively. The 42-day feed conversion (FC) for the 1957 broiler on the 1957 diets was 2.34, and for the 2001 broiler on the 2001 diet was 1.63. The 2001 broiler on the 2001 feed was estimated to have reached $1815 \mathrm{~g} \mathrm{BW}$ at 32 days of age with an FC of 1.47, whereas the 1957 broiler on the 1957 feed would not have reached that BW until 101 days of age with an FC of 4.42 . Their conclusion was that $85-90 \%$ of the improvement in the performance of broilers is due to genetic selection, and $10-15 \%$ due to nutrition (Havenstein et al., 2003).

Havenstein et al. (2003) also showed that the slaughter weight increases over the years. This distorts the trend of the feed conversion ratio (FCR) over the years. Therefore, LEI (currently Wageningen Economic Research) calculated the trend in FCR corrected to a slaughter weight of $2.15 \mathrm{~kg}$ based on Dutch data, which showed that the FCR decreases with almost $1 \%$ per year (Fig. 2). 


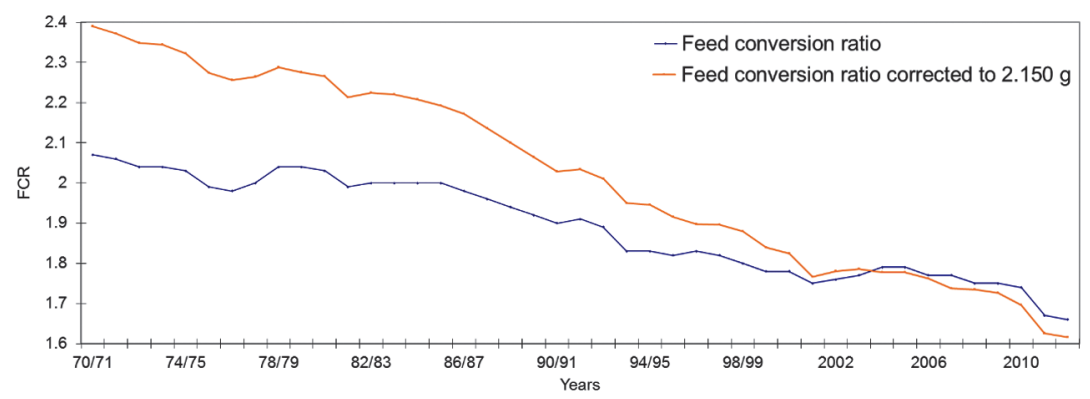

Figure 2 Trend in the feed conversion ratio of Dutch broilers (based on data from LEI (currently Wageningen Economic Research)).

Table 1 Summary data of broiler dataset with reference year, date of first and last placement, number of flocks, average number of animals per flock (Avg. numb.), average age at slaughter (Avg. age), average final body weight (after 1 day fasting) (Avg. weight) and average feed conversion ratio (Avg. FCR)

\begin{tabular}{lccccccc}
\hline Year & First & Last & \# flocks & Avg.numb. & $\begin{array}{c}\text { Avg. } \\
\text { age }\end{array}$ & $\begin{array}{c}\text { Avg. } \\
\text { weight }\end{array}$ & $\begin{array}{c}\text { Avg. } \\
\text { FCR }\end{array}$ \\
\hline 2014 & $07-05-13$ & $28-08-14$ & 12 & 33105 & 37.2 & 2.2 & 1.66 \\
2018 & $16-06-17$ & $07-08-18$ & 10 & 63716 & 40.3 & 2.7 & 1.56 \\
\hline
\end{tabular}

\subsection{Quantification of contribution of animal breeding}

\subsubsection{Materials and methods}

Data on the performance of Dutch commercial flocks were obtained from a broiler breeding company (Cobb Europe B.V., Boxmeer, The Netherlands) and contained 12 flocks with placement date in the period from May 2013 to August 2014, referred to as 2014, and 10 flocks from the period June 2017 to August 2018, referred to as 2018 (Table 1).

Feed composition was assumed to be equal in both periods and was derived from FeedPrint 2015.03 (Vellinga et al., 2013; Wageningen Livestock Research, 2015). Emissions of GHG related to the production offeed ingredients, and their $\mathrm{N}$ and $\mathrm{P}$ content, were collected from the database of FeedPrint 2018 (Wageningen Livestock Research, 2018).

Emissions of $\mathrm{GHG}$ are expressed in $\mathrm{CO}_{2}$ equivalents $\left(\mathrm{CO}_{2}\right.$-eq. $)$, which is a unit to express the contribution of different GHGs to their global warming potential (GWP), relative to $\mathrm{CO}_{2}$. Methane $\left(\mathrm{CH}_{4}\right)$ and nitrous oxide $\left(\mathrm{N}_{2} \mathrm{O}\right)$ have a GWP of respectively 36.75 (34 for biogenic $\mathrm{CH}_{4}$ ) and $298 \mathrm{CO}_{2}$-eq (Myhre et al., 2013).

Efficiencies of $\mathrm{N}$ and $\mathrm{P}$ are expressed in percentages and calculated as $\mathrm{N}$ and $P$ in output, for broilers in live animals, over input with feed. To express the output in $\mathrm{kg} \mathrm{N}$ and $\mathrm{P}$, body composition after 1 day fasting was based on Caldas (2015). 


\subsubsection{Results}

The environmental impact caused by GHG emissions from broiler production decreased with $1.6 \%$ per year, and $\mathrm{N}$ and $\mathrm{P}$ efficiency increased with $1.7 \%$ per year (Table 2). This decrease in environmental impact was fully caused by a decrease in FCR (Table 1, 1.5\%), which was larger than expected based on a literature overview of the development of FCR, where FCR decreased with about $1 \%$.

\subsubsection{Discussion}

As data were available only for the broiler growing phase, data analysis focused on this phase. This phase, however, is responsible for the vast majority of the GHG emissions of the whole broiler production chain (Fig. 1), with feed production in the broiler growing phase being responsible for $83 \%$ of total GHG emissions. Results, therefore, could be considered representative for the whole broiler production process.

The dataset used for this study was based on commercial flocks, instead of a research dataset. Therefore, it showed some peculiarities, for example, a considerable increase in flock size and age at slaughter, the latter also causing an increase in final body weight. These differences represent a global shift in slaughter weights for the broiler industry. However, for purposes of comparing GHG emissions, slaughter age and flock size differences could have contributed to an underestimation of the decrease in FCR, resulting in high reduction percentages. However, even with a more conservative estimation of $1 \%$ decrease in FCR, we could conclude that GHG emissions decrease and $\mathrm{N}$ and $P$ efficiency increases with the current breeding goal for broilers.

\section{Layers: environmental impact and the contribution of breeding}

\subsection{Historical trends}

Pelletier (2018) provided an evaluation on the extent of and plausible reasons for the change in the life cycle environmental footprint of conventional Canadian

Table 2 Emissions of GHG and N and P efficiency of broiler production in 2014 and 2018

\begin{tabular}{cccc}
\hline Year & $\begin{array}{c}\mathrm{GHG} \text { emissions } \\
\left(\mathrm{kg} \mathrm{CO}_{2} \text {-eq/kg BW }\right)\end{array}$ & $\begin{array}{c}\text { N efficiency } \\
(\%)\end{array}$ & $\begin{array}{c}\text { P efficiency } \\
(\%)\end{array}$ \\
\hline 2014 & 1.43 & 53.2 & 46.0 \\
2018 & 1.34 & 56.7 & 49.1 \\
\hline
\end{tabular}


egg production over a 50-year interval spanning from 1962 to 2012 . For this, the historical trajectory of the industry toward more sustainable practices was elucidated. Supply chain acidifying emissions declined by $61 \%$, eutrophying emissions by $68 \%$ and GHG emissions by $72 \%$. Despite the $>50 \%$ increase in annual egg production volumes - from 43.4 million dozen to 65.7 million dozen eggs in 1962 and 2012, respectively, the industry's overall environmental footprint actually decreased across all emissions and resource use domains considered. These observed changes are attributable to a combination of factors, including improved feed efficiency, changes in diet composition and manure management.

A similar study was performed by Pelletier et al. (2014) on the comparison of the environmental footprint of the egg industry in the United States in 1960 and 2010. They showed a similar reduction in GHG emissions by $71 \%$.

The increase in egg production and the decrease in FCR were also present in Dutch data (Fig. 3), based on national data collated yearly (KWIN, 2011, 2013, 2017).

\subsection{Quantification of contribution of animal breeding}

\subsubsection{Materials and methods}

For laying hens a full LCA model was available (Van Winkoop, 2013), which takes into account parent stock and layers, both including their rearing phase.

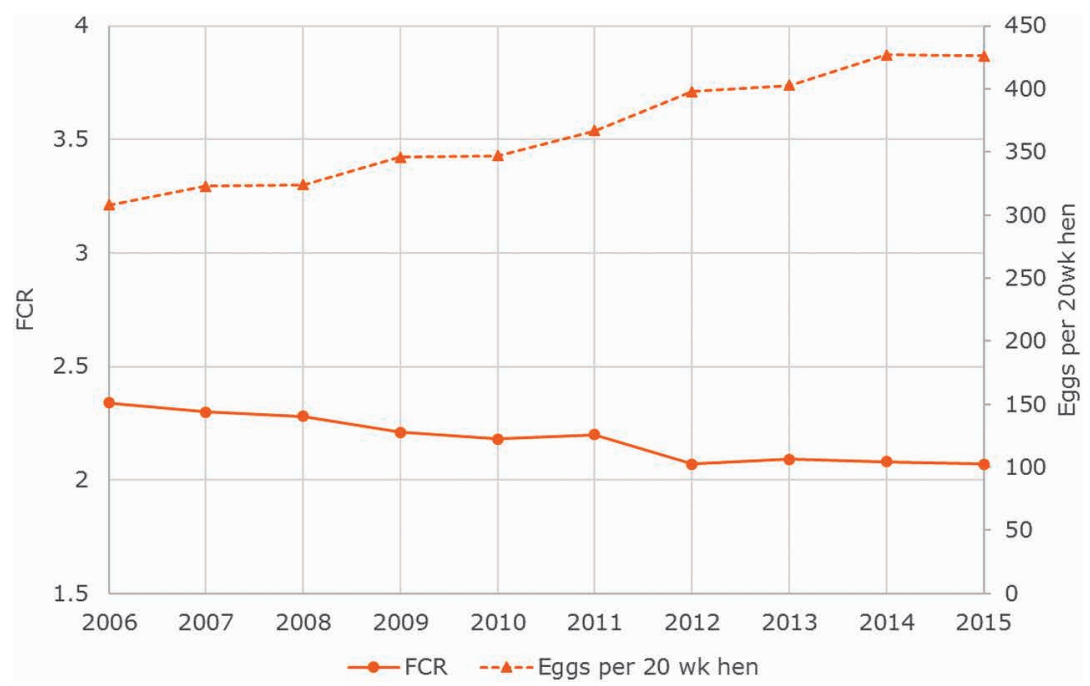

Figure 3 The trends in egg production and feed conversion ratios per Dutch laying hen from 2006 to 2015. 
For the calculation of genetic progress, however, only changes in the laying period were incorporated in the calculations.

Data on the development of modern commercial brown and white layer lines were obtained from a breeding company (Institut de Sélection Animale B.V. a Hendrix Genetics Company, Boxmeer, The Netherlands) and contained for the brown layers data for the years 2008 and 2017 (Table 3) and for the white layers for the years 2009 and 2017 (Table 3). These data should be considered to be from top-performing flocks and were available for the egg production phase only. These data were used to assess the rate of improvement, as this was anticipated to be representative for top-performing and average-performing commercial flocks. For a full LCA assessment, however, more data were needed and were derived from the 'commercial product' guides (Institut de Sélection Animale B.V. a Hendrix Genetics Company, Boxmeer, The Netherlands; Table 4). These data were also used for calculating environmental impacts for the commercial situation. It should be noted that these guides should hold for a broad range of commercial settings, including more challenging environments.

Feed composition was assumed to be equal in all periods and was derived from FeedPrint 2015.03 (Vellinga et al., 2013; Wageningen Livestock Research,

Table 3 Summary data of top-performing brown and white layers with reference year, total life time, mortality rate during laying period (from 18 weeks onwards), number of eggs per housed hen, total egg mass and average feed conversion ratio (Avg. FCR) during the laying period

\begin{tabular}{lcccccc}
\hline Line & Year & $\begin{array}{c}\text { Lifetime } \\
\text { (weeks) }\end{array}$ & $\begin{array}{c}\text { Mortality } \\
\text { rate }(\%)\end{array}$ & $\begin{array}{c}\text { Eggs per } \\
\text { housed hen }\end{array}$ & $\begin{array}{c}\text { Total egg } \\
\text { mass (kg) }\end{array}$ & Avg. FCR \\
\hline Brown & 2008 & 75 & 6 & 324 & 20.6 & 2.25 \\
& 2017 & 90 & 5 & 429 & 27.0 & 2.14 \\
\multirow{6}{*}{ White } & 2009 & 75 & 6 & 329 & 20.7 & 2.16 \\
& 2017 & 90 & 5 & 433 & 27.3 & 2.05 \\
\hline
\end{tabular}

Source: Institut de Sélection Animale B.V. a Hendrix Genetics Company, Boxmeer, The Netherlands.

Table 4 Summary data of commercial brown and white layers, total life time, mortality rate during laying period (from 18 weeks onwards), number of eggs per housed hen, total egg mass and average feed conversion ratio (FCR) during the laying period

\begin{tabular}{lccccc}
\hline Line & Lifetime (weeks) & Mortality rate (\%) & $\begin{array}{c}\text { Eggs per } \\
\text { housed hen }\end{array}$ & $\begin{array}{c}\text { Total egg } \\
\text { mass }(\mathrm{kg})\end{array}$ & Avg. FCR \\
\hline Brown & 80 & 7.8 & 353 & 22.1 & 2.29 \\
White & 90 & 7.5 & 411 & 25.9 & 2.24 \\
\hline
\end{tabular}

Source: Product guides, Institut de Sélection Animale B.V. a Hendrix Genetics Company, Boxmeer, The Netherlands. 
2015). Emissions of GHG related to the production of feed ingredients, and their $\mathrm{N}$ and $\mathrm{P}$ content, were collected from the database of FeedPrint 2018 (Wageningen Livestock Research, 2018).

Emissions of $\mathrm{GHG}$ are expressed in $\mathrm{CO}_{2}$ equivalents $\left(\mathrm{CO}_{2}\right.$-eq.), which is a unit to express the contribution of different GHG to global warming, their global warming potential (GWP), relative to $\mathrm{CO}_{2}$. Methane $\left(\mathrm{CH}_{4}\right)$ and nitrous oxide $\left(\mathrm{N}_{2} \mathrm{O}\right.$ ) have a GWP of, respectively, 36.75 (34 for biogenic $\mathrm{CH}_{4}$ ) and 298 $\mathrm{CO}_{2}$-eq (Myhre et al., 2013).

Efficiencies of $\mathrm{N}$ and $\mathrm{P}$ are expressed in percentages and calculated as $\mathrm{N}$ and $P$ in output over in put with feed. For laying hens, only eggs were considered as output and $\mathrm{N}$ and $\mathrm{P}$ contents were calculated with $\mathrm{N}$ and $\mathrm{P}$ content of raw egg (edible part; Finglas et al., 2015) applied to total egg mass (Tables 3 and 4) corrected for $15 \%$ shells (pers. Comm., Institut de Sélection Animale B.V. a Hendrix Genetics Company).

\subsubsection{Results}

Results for commercial brown and white layers (Table 5) show that impacts do not differ much.

The environmental impact caused by GHG emissions from egg production decreased by $0.7 \%$ per year for brown layers and by $0.9 \%$ per year for white layers (Table 6). $\mathrm{N}$ and $\mathrm{P}$ efficiency increased with $0.5 \%$ per year for brown layers and with $0.7 \%$ per year for white layers. The decrease in environmental impact was only partly caused by a decrease in FCR as also the production period was extended, due to genetic progress (Table 3). Especially for the assessment of GHG emissions, for which a full LCA including parent stock and rearing was used, the extended production period considerably contributed to the reduction of environmental impacts.

\subsubsection{Discussion}

As data for calculating genetic progress were only available for the laying period, total improvements could be expected to be larger when also improvements

Table 5 Emissions of GHG and N and P efficiency of egg production by commercial brown and white laying hens

\begin{tabular}{lccc}
\hline Line & $\begin{array}{c}\text { GHG emissions } \\
\left(\mathrm{kg} \mathrm{CO}_{2} \text {-eq } / \mathrm{kg} \mathrm{egg}\right)\end{array}$ & $\begin{array}{c}\text { Nefficiency } \\
(\%)\end{array}$ & $\begin{array}{c}\text { P efficiency } \\
(\%)\end{array}$ \\
\hline Brown & 2.18 & 30.2 & 15.5 \\
White & 2.09 & 30.9 & 15.8 \\
\hline
\end{tabular}


Table 6 Emissions of GHG and N and P efficiency of egg production by top-performing brown laying hens in 2008 and 2017

\begin{tabular}{lcccc}
\hline Line & Year & $\begin{array}{c}\text { GHG emissions } \\
\left(\mathrm{kg} \mathrm{CO}_{2} \text {-eq/kg egg) }\right.\end{array}$ & $\begin{array}{c}\text { N efficiency } \\
(\%)\end{array}$ & $\begin{array}{c}\text { P efficiency } \\
(\%)\end{array}$ \\
\hline Brown & 2008 & 2.18 & 30.6 & 15.7 \\
\multirow{3}{*}{ White } & 2017 & 2.03 & 32.0 & 16.4 \\
& 2009 & 2.10 & 31.9 & 16.3 \\
& 2017 & 1.95 & 33.5 & 17.1 \\
\hline
\end{tabular}

in parent stock and rearing would be taken into account. The laying period, however, is responsible for the vast majority of the GHG emissions of egg production (Fig. 1), with feed production in the laying period being responsible for $83 \%$ of total GHG emissions.

Based on this analysis we conclude that genetic progress is considerable in both brown and white layers, where white hens currently perform better and also improve faster than brown hens with respect to the environmental impact of production. As most brown hens produce brown eggs and most white hens produce white eggs and consumers in some countries prefer brown over white eggs, both types of layers still exist.

\section{Pigs: environmental impact and the contribution of breeding}

\section{1 Historical trends}

The feed efficiency of growing pigs has been a matter of serious commercial and scientific interest since at least 1970, but early recording technology made it difficult to produce accurate feed intake data at the individual level (Knap, 2009). Since electronic feeders were introduced, the pig breeding industry has been making good genetic improvement in feed conversion ratio (FCR), but this has been mainly due to genetic improvement of growth and body composition traits. A 35-year time trend illustrated by Knap and Wang (2012) shows very clearly that the average commercial FCR has come down from 3.3 to 2.6 , with a quite considerable bandwidth among terminal crosses which does not show any signs of narrowing over time (Fig. 4).

\subsection{Quantification of contribution of animal breeding}

\subsubsection{Materials and methods}

Data from an experiment, which is described in Sevillano et al. (2018), were obtained from a pig breeding company (Topigs Norsvin Research Center B.V., 


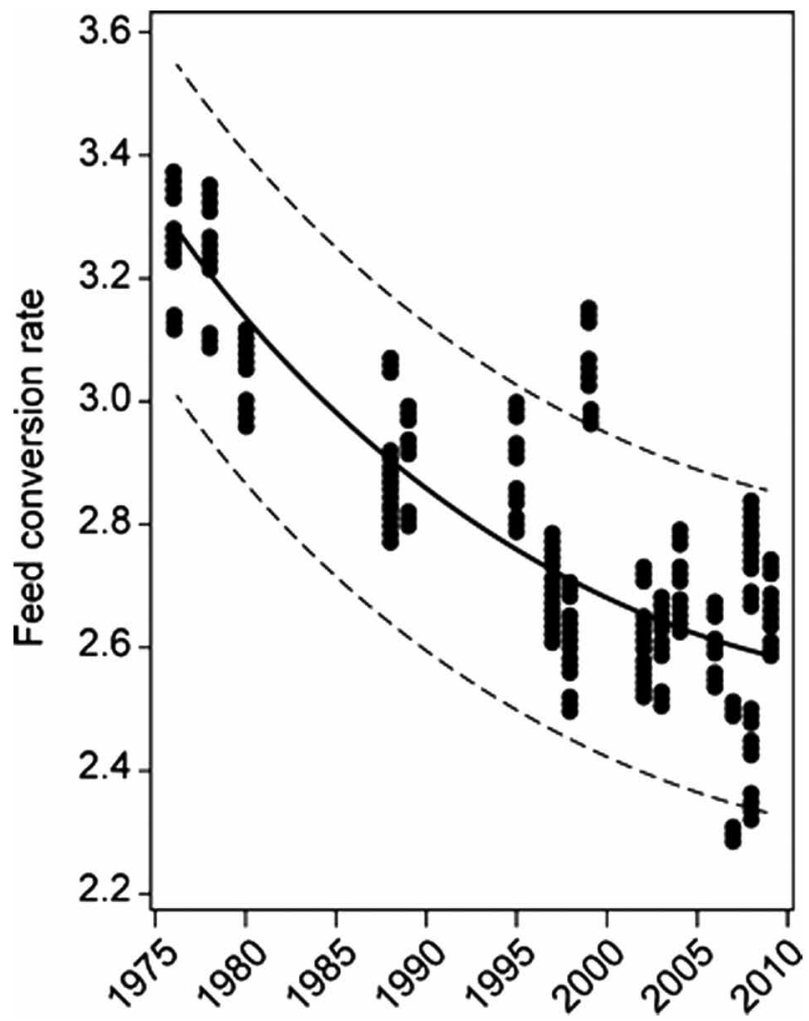

Figure 4 Time trends of feed conversion ratio in grower-finisher pigs of 103 terminal crosses, as recorded in public commercial product evaluation trials in Denmark, France, Germany, The Netherlands, UK and the United States. Unadjusted phenotypic population means, data from 18 literature and internet sources. The trend line is a spline interpolation plot through the data, with its $95 \%$ confidence limits. Figure copied from Knap and Wang (2012).

Beuningen, The Netherlands). In this experiment a corn/soybean meal (CS) diet and a cereals/alternative ingredient (CA) diet was fed to intact boars and gilts. The CS diet resembles American practice, but the impact of feed ingredients was calculated as fed in The Netherlands, which means, for example, that soybean meal mainly originated from Argentina and Brazil. The CA diet resembles Dutch practice, with many by-products in the diet. For calculating genetic progress, data from 400 pigs in 2014 (December 2013-May 2014) and 401 pigs in 2016 (November 2015-March 2016) were used (Table 7). Data only considered the growing-finishing phase (i.e., from $22 \mathrm{~kg}$ to approximately $120 \mathrm{~kg}$ of live weight). Feed composition was derived from Sevillano et al. (2018).

Emissions of GHG related to the production of feed ingredients, and their $\mathrm{N}$ and $\mathrm{P}$ content, were collected from the database of FeedPrint 2018 
(Wageningen Livestock Research, 2018). Emissions of GHG are expressed in $\mathrm{CO}_{2}$ equivalents $\left(\mathrm{CO}_{2}\right.$-eq.), which is a unit to express the contribution of different GHG to global warming, their global warming potential (GWP), relative to $\mathrm{CO}_{2}$. Methane $\left(\mathrm{CH}_{4}\right)$ and nitrous oxide $\left(\mathrm{N}_{2} \mathrm{O}\right)$ have a GWP of respectively 36.75 (34 for biogenic $\mathrm{CH}_{4}$ ) and $298 \mathrm{CO}_{2}$-eq (Myhre et al., 2013). Efficiencies of $\mathrm{N}$ and $\mathrm{P}$ are expressed in percentages and calculated as $N$ and $P$ in output over input with feed. Protein deposition was calculated as described by Sevillano et al. (2018) and was used to calculate $\mathrm{N}$ deposition, whereas $\mathrm{P}$ deposition was calculated based on Pettey et al. (2015).

\subsubsection{Results}

The environmental impact caused by GHG emissions from pig production decreased by $0.6-0.7 \%$ per year dependent on the diet (Table 8). Nitrogen efficiency increased by $1.6-1.7 \%$, whereas $P$ efficiency increased by $0.4-0.6 \%$ over the two years. On all environmental indicators, boars performed slightly better than gilts. The $\mathrm{N}$ efficiency could be calculated more precisely than $\mathrm{P}$ efficiency because back fat thickness was measured in the experiment and used to calculate protein deposition. Therefore, the decrease in environmental impact was not only caused by a decrease in FCR (lower feed intake at same growth rate; Table 7) but also by higher protein deposition at similar growth.

\subsubsection{Discussion}

Data analysis focused on the grower-finisher phase because good-quality, detailed information was available for this phase. Furthermore, the chosen method for GHG emission calculation accounted for the effect of feed production on GHG emissions only. The full analysis of the whole production cycle could have given different results, as Groen et al. (2016) showed that $\mathrm{CH}_{4}$ emissions from manure management, crop yields and reproduction performance are important processes determining whole chain GHG emissions from pig production. These results correspond well with data, shown in Fig. 1, where reproduction and rearing phase (27\%) and emissions from manure (25\%) contribute considerably to the total impact of pig production. Groen et al. (2016), however, also showed that FCR is the most important factor, with the highest influence on whole chain GHG emission from pig production. This is in agreement with the data shown in Fig. 1, where feed production alone explains more than $40 \%$ of GHG emissions from pig production.

Differences in the environmental impact of pigs, fed either a CS or CA diet, were most clear in $P$ efficiency, caused by low digestibility of $P$ in some by-products in the CA diet (e.g., rapeseed and sunflower meal). When the CS diet would have been calculated as fed in the country where corn and soybean 


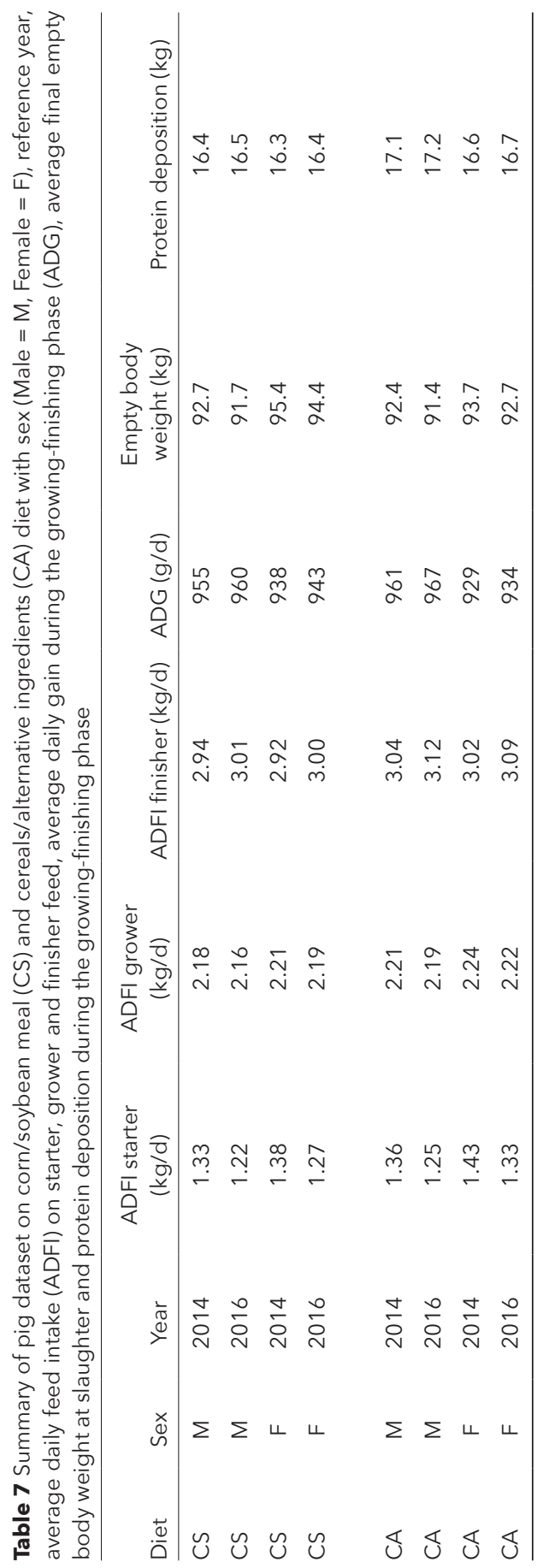


Table 8 Emissions of GHG and N and P efficiency of male (M) and female (F) pigs on corn/ soybean meal (CS) and cereals/alternative ingredients (CA) diet in 2014 and 2016

\begin{tabular}{lccccc}
\hline Diet & Yex & Year & $\begin{array}{c}\text { GHG emissions } \\
\text { (kg CO} \\
\text { kg BW gain) }\end{array}$ & $\begin{array}{c}\text { N efficiency } \\
(\%)\end{array}$ & $\begin{array}{c}\text { P efficiency } \\
(\%)\end{array}$ \\
\hline CS & M & 2014 & 1.93 & 44.7 & 36.8 \\
CS & M & 2016 & 1.90 & 46.2 & 37.3 \\
CS & F & 2014 & 1.99 & 43.2 & 36.9 \\
CS & F & 2016 & 1.96 & 44.7 & 37.3 \\
& & & & & \\
CA & M & 2014 & 1.70 & 43.7 & 25.8 \\
CA & M & 2016 & 1.68 & 45.1 & 26.1 \\
CA & F & 2014 & 1.78 & 41.2 & 25.3 \\
CA & F & 2016 & 1.76 & 42.5 & 25.5 \\
\hline
\end{tabular}

were grown, GHG impacts of pigs fed the CS diets probably would have been lower.

From this analysis we could conclude that current breeding goals decrease the environmental impact of producing pig meat and that boars are more efficient and, therefore, have a lower environmental impact than gilts.

\section{Dairy cattle: environmental impact and the contribution of breeding}

\subsection{Historical trends}

Over the past 100 years, the range of traits considered for genetic selection in dairy cattle populations has progressed to meet the demands of both industry and society (Miglior et al., 2017). At the turn of the twentieth century, dairy farmers were interested in increasing milk production; however, a systematic strategy for selection was not available. Organized milk performance recording took shape, followed quickly by conformation scoring. Methodological advances in both genetic theory and statistics around the middle of the century, together with technological innovations in computing, paved the way for powerful multi-trait analyses. As more sophisticated analytical techniques for traits were developed and incorporated into selection programs, production began to increase rapidly, and the wheels of genetic progress began to turn. By the end of the century, the focus of selection had moved away from being purely production oriented toward a more balanced breeding goal. This shift occurred partly due to increasing health and fertility issues and partly due to societal pressure and welfare concerns. Traits encompassing longevity, fertility, calving, and health, have now been integrated into national selection indices. 
With these indices, milk production is still increasing per year. As shown in Fig. 5, milk production in The Netherlands has increased by $46 \%$ between 1990 and 2017. Because of the increased milk production, the feed intake has increased but to a lesser extent than milk production; therefore, the efficiency of dairy production ( $\mathrm{kg}$ milk/kg feed) has improved over the years.

\subsection{Quantification of contribution of animal breeding}

\subsubsection{Selection indices}

Selection indexes are utilized by livestock breeders of many species around the world and aid in the selection of animals for use within a breeding program where there are several traits of economic or functional importance. Selection indexes provide an overall 'score' of an animal's genetic value for a specific purpose and are calculated based on weightings placed on individual traits that are deemed to be important for that purpose. Selection indexes assist producers in making 'balanced' selection decisions. The derivation of a selection index starts with the definition of the overall breeding objective.

The next stage in developing a selection index is to calculate economic values for each trait, generally with a bio-economic model, where the economic value is the increase in revenue from a unit change of a trait while everything else is held constant. Then, selection index theory (Hazel, 1943) is commonly used to calculate the most appropriate index weights and responses to

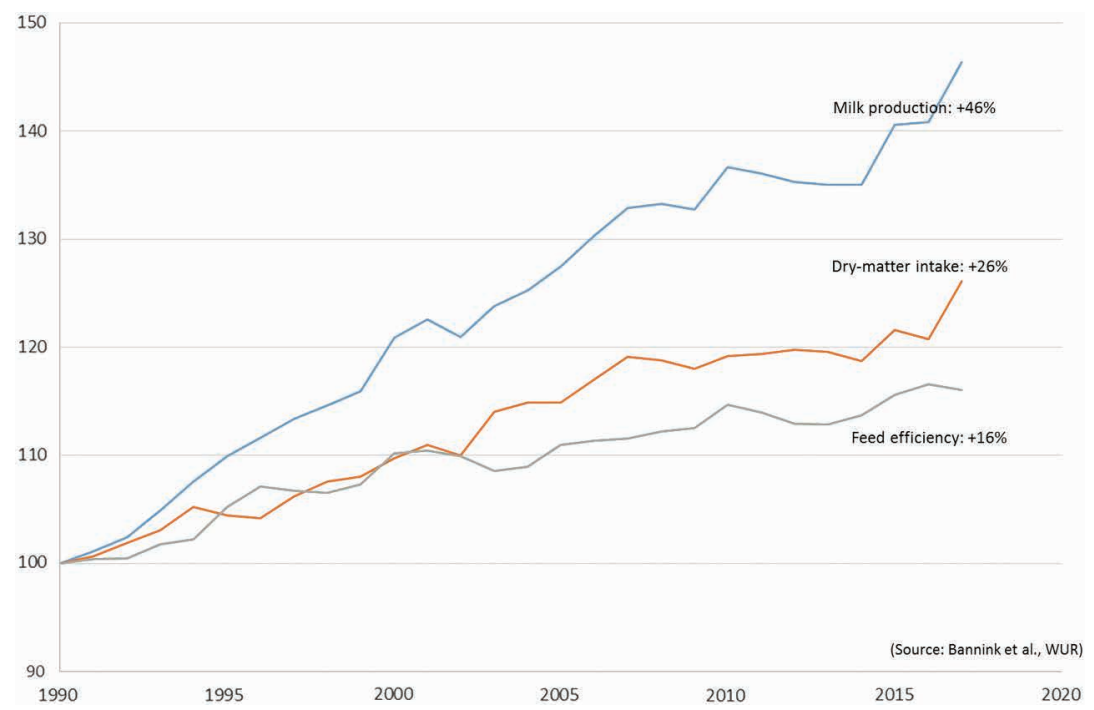

Figure 5 Trends in milk yield, feed intake and feed efficiency of the Dutch dairy cattle population between 1995 and 2017 (extended and based on Bannink et al. (2011)). 
selection for a set of traits given the genetic and phenotypic (co)variances and the economic values of traits in the index. The resulting selection index is the sum of $n$ estimated breeding values (EBVi) for each trait multiplied by their respective index weights $b_{i}$.

$$
\text { Index }=b_{1} E B V 1+b_{2} E B V 2+\ldots+b_{n} E B V n
$$

\subsubsection{Quantification effect of breeding}

In our case, we started with a selection index representing the national breeding goal for dairy cattle of The Netherlands (CRV, 2018). The Dutch national breeding goal consists of milk component traits, longevity, health traits (udder health, claw health), fertility traits (interval first-last insemination, calving interval), conformation traits (for udder and for feed and legs), calving traits (calving ease and vitality of calves) and feed efficiency (Table 9). We added enteric $\mathrm{CH}_{4}$ emissions to this index as a correlated trait. Genetic parameters were obtained from the literature (Lassen and Lovendahl, 2016). The heritability for enteric $\mathrm{CH}_{4}$ production is 0.21 , and genetic correlations with milk lactose, protein, fat and dry matter intake are $0.43,0.37,0.77$ and 0.42 ( -0.42 for feed saved), respectively. Correlations between enteric $\mathrm{CH}_{4}$ production and other traits in the breeding goal were set to zero. All phenotypic correlations were also set to zero.

Selection index calculations show how much the traits are predicted to change per year. This is plotted in Fig. 6 for both $\mathrm{CH}_{4}$ production $(\mathrm{g} / \mathrm{d})$ and for $\mathrm{CH}_{4}$ intensity $\left(\mathrm{CH}_{4}\right.$ production expressed per $\mathrm{kg}$ of milk). It shows that $\mathrm{CH}_{4}$ production per cow will steadily increase as a correlated response to selection for the current breeding goal. However, the methane intensity drops. Further reductions could be achieved when actively selecting on lower methaneemitting cows, by adding more weight on $\mathrm{CH}_{4}$ in the national breeding goal. Selecting actively against methane would result in healthy, fertile, long-living cows that emit less $\mathrm{CH}_{4}$. Actively selecting against $\mathrm{CH}_{4}$ emission, however, requires large-scale recording of individual $\mathrm{CH}_{4}$ emissions.

\subsubsection{Discussion}

The predicted future trends in enteric methane production are based on the genetic parameters used in the selection indices. The correlation of 0.77 between protein yield and enteric methane production is strong and impacts the results. Further research is needed to estimate reliable genetic parameters between enteric methane production and other traits of interest (e.g., the traits in the breeding goal). Estimating these genetic parameters requires that a large enough dataset is built, which includes records of enteric $\mathrm{CH}_{4}$ emission of many individual cows. 


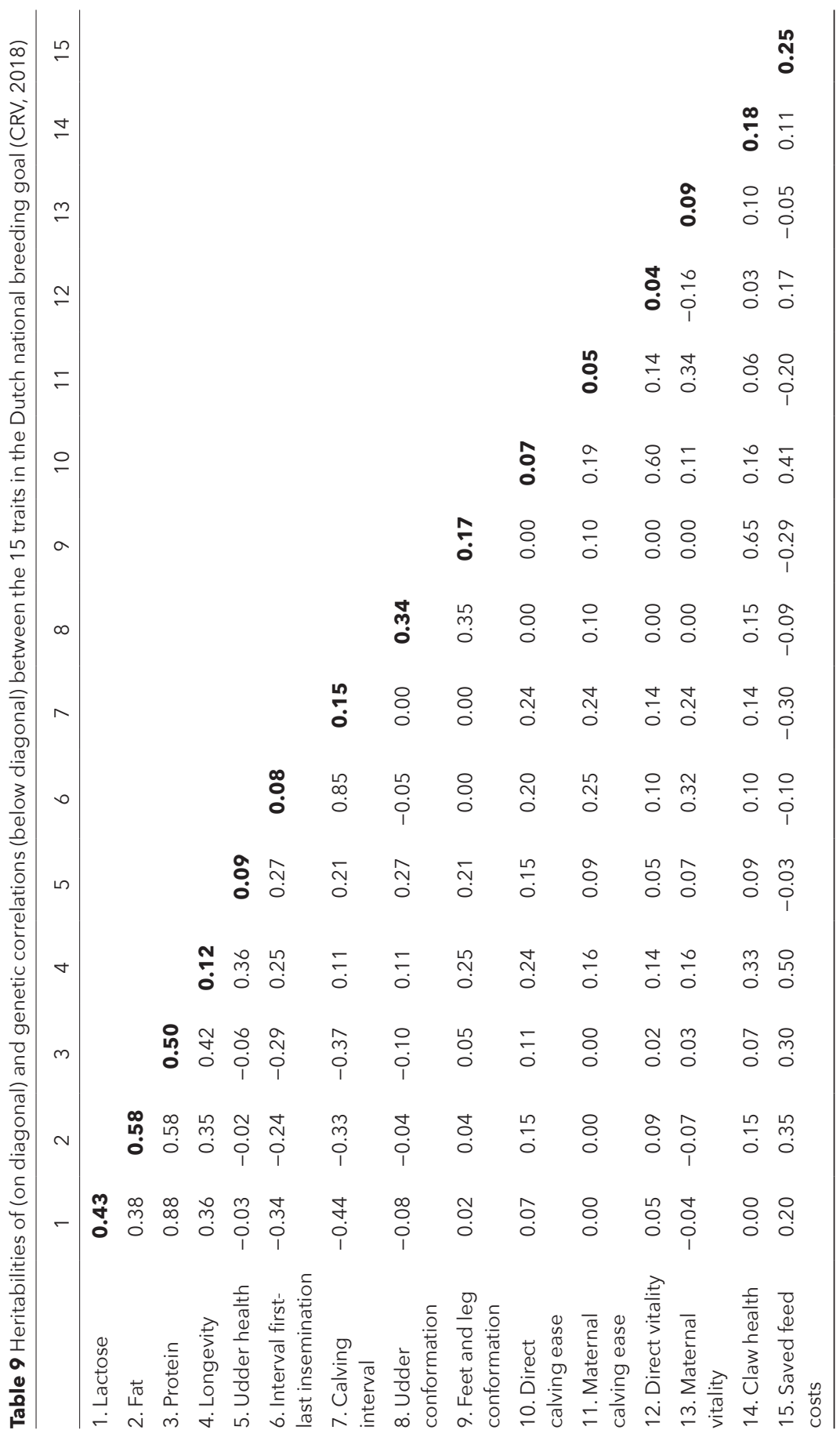


$120.00 \%$

$100.00 \%$

$80.00 \%$

$60.00 \%$

$40.00 \%$

$20.00 \%$

- methane production

- methane intensity

$0.00 \%$

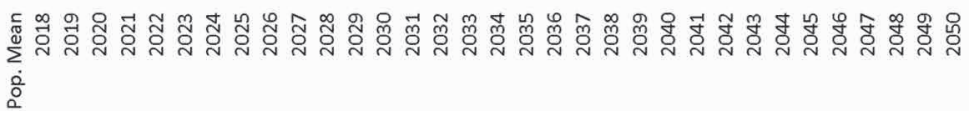

Figure 6 Expected future trends in $\mathrm{CH}_{4}$ production $\left(\mathrm{g} / \mathrm{d}\right.$ ) and $\mathrm{CH}_{4}$ intensity $(\mathrm{g} / \mathrm{kg}$ milk) for the Dutch dairy cattle population with breeding on the current national breeding goal.

\section{Conclusion}

Animal production is responsible for $14.5 \%$ of total anthropogenic GHG emissions. Approximately half of these emissions originate directly from animal production, whereas the other half comes from feed production. Animal breeding aims at improving animal production and efficient use of resources, which results in a reduction of the environmental impact. The objective of this study was to quantify the contribution of animal breeding in reducing the environmental impact of the four major livestock species in The Netherlands, namely broilers (meat), laying hens (eggs), pigs (meat) and dairy cattle (milk).

A literature review was performed to assess the current status of and historical trends in environmental impact, mainly focused on GHG emissions, and general performance criteria, like feed efficiency and lifetime production. Emissions related to the feed production dominate the impacts by broilers and laying hens. For pigs, the emissions during feed production and from manure are important contributors. For dairy cattle, as being ruminants, enteric methane emission is a large contributor to total GHG emissions. Historical trends show considerable improvements in efficiency over the last decades, in which breeding has an important role. The literature review showed that the contribution of breeding to reducing the environmental impact of animal production is led by an indirect response through selection on increased efficiency. 
Also a quantitative assessment was made on the current environmental impact of the four animal products and the effect of recent genetic improvements. For broiler meat, chicken eggs and pig meat the focus was on GHG emissions, and nitrogen (N) and phosphorus (P) efficiency, whereas for dairy the focus was on enteric methane emissions, an important contributor to GHG emissions. Data were partly provided by breeding organizations, that is, the partners in the Breed4Food consortium (www.breed4food.com).

The analyses in this chapter demonstrate that animal breeding can provide a mitigation tool to lower the environmental impact of livestock species. Genetic improvement of livestock is a particularly cost-effective technology, producing permanent and cumulative changes in performance:

- For broilers, it was shown that GHG emissions decreased with $1.7 \%$ and $\mathrm{N}$ and $\mathrm{P}$ efficiency increased by $1.6 \%$ per year due to the current breeding goals

- For laying hens, white and brown hens were considered and it was concluded that white hens currently have a lower GHG impact and better $\mathrm{N}$ and $\mathrm{P}$ efficiency than brown hens and that improvements over the past 10 years went faster for white hens.

- For pigs, data were available from a well-controlled study with two diets and animals divided by sex over a time frame of two years. Results showed that in the growing-fattening phase of pigs, GHG emissions decrease and $\mathrm{N}$ and $\mathrm{P}$ efficiency increase with the current breeding goal. Furthermore, boars had a lower environmental impact than gilts.

- For dairy cattle, results showed that with the current breeding goal, $\mathrm{CH}_{4}$ production per cow per day increases but $\mathrm{CH}_{4}$ intensity (i.e., $\mathrm{CH}_{4}$ production per kg milk) decreases.

All reported results are achieved without specific selection on environmental traits, but as an indirect response of the current breeding goals for each species, which is a combination of health, growth and (feed) efficiency. If direct selection of environmental traits is desired, recording of new traits is required, for example, $\mathrm{N}$ and $\mathrm{P}$ contents of meat and eggs and methane emission of individual dairy cows.

Direct measurement of GHG impact of animal production is difficult, but not impossible, which hampers active selection against GHG emissions of animals. In the short run, indirect selection against GHG emissions could be further optimized by putting more selection pressure on efficiency traits, while accounting for the effects on other important traits, for example, health, longevity and reproduction. In the long run, recording schemes could be set up to either record the desired traits on commercial farms (for dairy) or in parental stock (for pigs and poultry).

The LCA analyses performed in this study could be further improved by also including information of the parent stock and rearing phases. It is expected that 
when including genetic progress in parent stock and rearing phases of parents and commercials, the contribution of genetics to reduce GHG emissions per $\mathrm{kg}$ product has an even bigger impact.

\section{Where to look for further information}

\subsection{Further reading}

Selection index theory: Hazel L.N. (1943) The genetic basis for constructing selection indexes. Genetics 28, 476-490. \& Lush J.L. (1960) Improving dairy cattle by breeding. I. Current status and outlook. Journal of Dairy Science 43, 702-706.

LCA analyses: Thomassen M.A. and De Boer I.J.M. (2005) Evaluation of indicators to assess the environmental impact of dairy production systems. Agriculture, Ecosystems \& Environment 111: 185-199. \& De Vries M. and De Boer I.J.M. (2010) Comparing environmental impacts for livestock products: A review of life cycle assessments. Livestock Science 128, 1-11.

Report on 'The contribution of breeding to reducing environmental impact of animal production', https://library.wur.nl/WebQuery/wurpubs/549934

\subsection{Key conferences}

WCGALP (world conference of genetics applied to animal production) is well attended by members of the animal breeding community (industry and scientists).

GGAA (greenhouse gas of agriculture and animal) is well attended by scientists in all disciplines (nutrition, breeding, microbiology, etc.) working on the reduction of environmental impact of livestock production.

\section{Acknowledgments}

This study was financially supported by the Dutch Ministry of Economic Affairs (TKI Agri \& Food project 16022) and the Breed4Food Partners Cobb Europe, CRV, Hendrix Genetics and Topigs Norsvin.

\section{References}

Bannink, A., Van Schijndel, M. W. and Dijkstra, J. (2011). A model of enteric fermentation in dairy cows to estimate methane emission for the Dutch National Inventory Report using the IPCC Tier 3 approach. Anim. Feed Sci. Technol., 166-167: 603-618.

Caldas, J. (2015). Calorimetry and Body Composition Research in Broilers and Broiler Breeders. Fayetteville, AR: University of Arkansas, 243. 
CRV. (2018). Statistical indicators, E-20. NVI. Available at: https://www.cooperatie-crv.nl/ wp-content/uploads/2018/10/E_20-NVI_aug2018_en.pdf.

De Vries, M. and De Boer, I. J. M. (2010). Comparing environmental impacts for livestock products: A review of life cycle assessments. Livest. Sci., 128(1-3): 1-11.

Delgado, C., Rosegrant, M., Steinfeld, H., Ehui, S. and Courbois, C. (1999). Livestock to 2020 - The Next Food Revolution. Food, Agriculture, and the Environment Discussion. Washington, D.C.; Rome, Italy; Nairobi, Kenia: International Food Policy Research Institute; Food and Agriculture Organization of the United Nations; International Livestock Research Institute.

FAO. (2009). How to feed the world in 2050. Available at: http://www.fao.org/fileadmin/t emplates/wsfs/docs/expert_paper/How:to_Feed_the_World_in_2050.pdf.

Finglas, P., Roe, M., Pinchen, H., Berry, R., Church, S. and Dodhia, S. (2015). McCance and Widdowson's the Composition of Foods Integrated Dataset 2015 - User Guide. London, UK: Public Health England. PHE publications gateway number: 2014822.

Gerber, P. J., Steinfeld, H., Henderson, B., Mottet, A., Opio, C., Dijkman, J., Falcucci, A. and Tempio, G. (2013). Tackling Climate Change through Livestock - A Global Assessment of Emissions and Mitigation Opportunities. Rome, Italy: Food and Agriculture Organization of the United Nations (FAO).

Groen, E. A., van Zanten, H. H. E., Heijungs, R., Bokkers, E. A. M. and de Boer, I. J. M. (2016). Sensitivity analysis of greenhouse gas emissions from a pork production chain. J. Clean. Prod., 129: 202-211.

Havenstein, G. B., Ferket, P. R. and Qureshi, M. A. (2003). Growth, livability, and feed conversion of 1957 versus 2001 broilers when fed representative 1957 and 2001 broiler diets. Poult. Sci., 82(10): 1500-1508.

Hazel, L. N. (1943). The genetic basis for constructing selection indexes. Genetics, 28(6): 476-490.

Herrero, M., Gerber, P., Vellinga, T., Garnett, T., Leip, A., Opio, C., Westhoek, H. J., Thornton, P. K., Olesen, J., Hutchings, N., Montgomery, H., Soussana, J.-F., Steinfeld, H. and McAllister, T. A. (2011). Livestock and greenhouse gas emissions: The importance of getting the numbers right. Anim. Feed Sci. Technol., 166-167: 779-782.

Johnson, K. A. and Johnson, D. E. (1995). Methane emissions from cattle. J. Anim. Sci., 73(8): 2483-2492.

Knap, P. W. (2009). Voluntary feed intake and pig breeding. In: Torrallardona, D. and Roura, E. (Eds) Voluntary Feed Intake in Pigs. Wageningen, the Netherlands: Wageningen Academic Publishers.

Knap, P. W. and Wang, L. (2012). Pig breeding for improved feed efficiency. In: Patience, J. F. (Ed.) Feed Efficiency in Swine. Wageningen, the Netherlands: Wageningen Academic Publishers.

KWIN. (2011). Kwantitatieve Informatie Veehouderij 2011-2012. Wageningen, the Netherlands: Wageningen Livestock Research.

KWIN. (2013). Kwantitatieve Informatie Veehouderij 2013-2014. Wageningen, the Netherlands: Wageningen Livestock Research.

KWIN. (2017). Kwantitatieve Informatie Veehouderij 2017-2018. Wageningen, the Netherlands: Wageningen Livestock Research.

Lassen, J. and Lovendahl, P. (2016). Heritability estimates for enteric methane emissions from Holstein cattle measured using noninvasive methods. J. Dairy Sci., 99(3): 1959-1967. 
Miglior, F., Fleming, A., Malchiodi, F., Brito, L. F., Martin, P. and Baes, C. F. (2017). A 100year review: Identification and genetic selection of economically important traits in dairy cattle. J. Dairy Sci., 100(12): 10251-10271.

Mu, W., van Middelaar, C. E., Bloemhof, J. M., Oenema, J. and de Boer, I. J. M. (2016). Nutrient balance at chain level: A valuable approach to benchmark nutrient losses of milk production systems. J. Clean. Prod., 112: 2419-2428.

Myhre, G., Shindell, D., Bréon, F.-M., Collins, W., Fuglestvedt, J., Huang, J., Koch, D., Lamarque, J.-F., Lee, D., Mendoza, B., Nakajima, T., Robock, A., Stephens, G., Takemura, T. and Zhang, H. (2013). Anthropogenic and natural radiative forcing. In: Stocker, T. F., Qin, D., Plattner, G.-K., Tignor, M., Allen, S. K., Boschung, J., Nauels, A., Xia, Y., Bex, V. and Midgley, P. M. (Eds) Climate Change 2013: The Physical Science Basis. Contribution of Working Group I to the Fifth Assessment Report of the Intergovernmental Panel on Climate Change. Cambridge, UK and New York, NY: Cambridge University Press.

O'Mara, F. P. (2011). The significance of livestock as a contributor to global greenhouse gas emissions today and in the near future. Anim. Feed Sci. Technol., 166-167: 7-15.

Pelletier, N. (2018). Changes in the life cycle environmental footprint of egg production in Canada from 1962 to 2012. J. Clean. Prod., 176: 1144-1153.

Pelletier, N., Ibarburu, M. and Xin, H. (2014). Comparison of the environmental footprint of the egg industry in the United States in 1960 and 2010. Poult. Sci., 93(2): 241-255.

Pettey, L. A., Cromwell, G. L., Jang, Y. D. and Lindemann, M. D. (2015). Estimation of calcium and phosphorus content in growing and finishing pigs: Whole empty body components and relative accretion rates. J. Anim. Sci., 93(1): 158-167.

Sevillano, C. A., Nicolaiciuc, C. V., Molist, F., Pijlman, J. and Bergsma, R. (2018). Effect of feeding cereals-alternative ingredients diets or corn-soybean meal diets on performance and carcass characteristics of growing-finishing gilts and boars. J. Anim. Sci., 96(11): 4780-4788.

Steinfeld, H., Gerber, P., Wassenaar, T., Castel, V., Rosales, M. and De Haan, C. (2006). Livestock's Long Shadow: Environmental Issues and Options. Rome, Italy: Food and Agriculture Organization of the United Nations.

Thomassen, M. A. and de Boer, I. J. M. (2005). Evaluation of indicators to assess the environmental impact of dairy production systems. Agric. Ecosyst. Environ., 111(14): 185-199.

Van Winkoop, C. (2013). The contribution of layer chicken breeding to the reduction of climate change. Wageningen, the Netherlands: Wageningen University; Animal Breeding and Genomics Centre, 44.

Vellinga, T. V., Blonk, H., Marinussen, M., Van Zeist, W. J., De Boer, I. J. M. and Starmans, D. (2013). Methodology Used in FeedPrint: A Tool Quantifying Greenhouse Gas Emissions of Feed Production and Utilization. Wageningen, the Netherlands: Wageningen UR Livestock Research, 121. http://edepot.wur.nl/254098.

Wageningen Livestock Research. (2015). FeedPrint 2015.03. Wageningen, the Netherlands: Wageningen University and Research.

Wageningen Livestock Research. (2018). FeedPrint 2018.01. Wageningen, the Netherlands: Wageningen University and Research.

Williams, A. G., Audsley, E. and Sandars, D. L. (2006). Determining the Environmental Burdens and Resource Use in the Production of Agricultural and Horticultural Commodities. Bedford: Cranfield University and Defra. 
